\title{
The Use of Battery Bank for Rationalization of Electricity in Broiler Poultry Farms
}

\author{
Ana Carolina Sala Moreno ${ }^{1}$, Jair Antonio Cruz Siqueira ${ }^{1} \&$ Carlos Eduardo Camargo Nogueira ${ }^{1}$ \\ ${ }^{1}$ Universidade Estadual do Oeste do Paraná, Cascavel, Paraná, Brazil \\ Correspondence: Ana C. S. Moreno, Universidade Estadual do Oeste do Paraná, Universitária Street, 2069, Zip \\ Code 85819-110, Cascavel, Paraná, Brazil. Tel: 55-45-3025-7787. E-mail: carolsalamoreno@hotmail.com
}

Received: April 18, 2018

Accepted: June 4, $2018 \quad$ Online Published: July 15, 2018

doi:10.5539/jas.v10n8p253

URL: https://doi.org/10.5539/jas.v10n8p253

\begin{abstract}
Electricity is one of the main inputs used in poultry production. An aviary needs electricity to feed the various motors and electrical devices that compose the lighting systems, exhaustion, heating, food, among others. Aiming to give incentives to producers of broiler chickens, specifically in the state of Paraná, Brazil, in 2007, the Night Poultry Program was implemented, in which the government grants discounts in electricity tariff for poultry farmers at night. In this work it was proposed two energy storage systems through the use of lead-acid batteries and batteries of nickel chloride and sodium to feed the of charge of four brazillian aviaries over one year of poultry housing. For this purpose, it was evalueted the use of a bank of batteries in higher tariff, period comprising the time of 9:30 pm to 6 am of the next day, and charging the battery bank in reduced tariff period. The experiment was conducted using the electricity meters installed in the aviaries, weekly data of each aviary were collected and the active energy values, obtaining the data for six lots corresponding to a year of poultry accommodation. From the total consumption of active energy, it was calculated the average daily electricity consumption (kWh) for the set of aviaries. This value was used as input for the sizing of the battery banks. The two proposed storage systems demonstrate an alternative to energy supply for the rural areas, however the economical analysys indicates inviability, since the initial investment of the banks of batteries is high compared with the costs avoided with electricity by using these systems.
\end{abstract}

Keywords: energy storage, lead-acid battery, nickel and sodium chloride battery

\section{Introduction}

According to the Associação Brasileira dos Produtores e Exportadores de Frangos (2014), in 2013 Brazil was ranked the third place in the world chicken meat production, behind only the United States and China. As for exports, Brazil has, since 2004, the world's largest exporter position, ending 2013 with approximately 3.9 million tons shipped to over one hundred and fifty countries. It is remarkable the importance of this segment in Brazil, especially when there is the presence of a large number of producers within the country, highlighting the states in the South, Southeast and Midwest.

In this context, the state of Paraná represented $29.35 \%$ of chicken slaughter carried out in the country in 2013, occupying the position of the largest chicken exporter state of the country. In the sequence were the states of Santa Catarina, Rio Grande do Sul, São Paulo, Minas Gerais, Goiás, Mato Grosso, Mato Grosso do Sul and the Federal District.

It is known that poultry production requires the use of electricity to supply the power necessary for the operation and maintenance of aviaries, once many engines and electrical devices are used for the operation of exhaustion systems, cooling, heating, misting, food, lighting, among others that compose the poultry breeding of broiler chickens. According to Calixto and Oliveira (2012), the energy expenses account for approximately $10 \%$ of the broilers production costs.

In this sense, the spent values with electricity have been a constant concern in the poultry production sector, since farmers are conformed in this segment, especially for utilities in some states of Brazil, in a kind of electric power that at certain times of the day, the value of the electricity tariff is higher.

Specifically in the state of Paraná, in 2007, it was created the Night Poultry Program by state government in partnership with the State Department of Agriculture and Food Supply and Companhia Paranaense de Energia 
Elétrica. This program encouraged the increase of the agricultural production for poultry and pig farmers through tariff reductions for consumer units classified as rural, attended at low voltage. According to the Agência Nacional de Energia Elétrica (2014), through this program the poultry farmers may have discounts on electricity tariff used in poultry production at night, comprising the time of 9:30pm to 6 am of the next day.

Unlike industries that, as far as possible, seek to move their charges to times when the electricity rate is lower, the aviaries have continuous demand for electricity, once, if the systems such as lighting, ventilation, heating, cooling and power were interrupted could impact the performance of poultry production. In this context, most farmers do not use other forms of electricity supply but power from the local power utility.

In this sense, the possibility of using batteries can represent enormous potential for service charges of poultry, whether partial or total, especially in times of higher electricity rates. Yan, Zhang, Chen, Xu, and Tan (2013) did a techno-economic and social analysis of energy storage for commercial buildings in Beijing, China, According to the authors, the rate of electricity to commercial consumers variates according to the time of utilization. An energy storage system can be operated during the peak time and recharged out of peak time.

The objective of this study is evaluate technical and economic aspects of the use of lead-acid and nickel chloride and sodium batteries to the electrical energy storage seeking the electricity supply in the higher electricity tariff schedule in four Brazillian broiler poultry farms.

It should be noted that energy conservation, according to the Centrais Elétricas Brasileiras S.A. (2015), includes the efficient use of electric energy, reduce waste, the use of more efficient equipment and systems, helping to preserve the environment and to reduce costs and investments.

\section{Method}

The experiment was conducted in four broiler poultry farms located in the city of Francisco Alves, state of Paraná, Brazil, with geographical coordinates of latitude $20^{\circ} 02^{\prime} 04^{\prime \prime} \mathrm{S}$ and longitude $53^{\circ} 52^{\prime} 51^{\prime \prime} \mathrm{W}$.

The four aviaries in the study have the following constructive physical characteristics:

Aviaries 1 and 2: the dimensions of aviaries 1 and 2 are $12 \mathrm{~m}$ wide by $125 \mathrm{~m}$ long and $2.95 \mathrm{~m}$ high, covered with clay tiles, with side low walls with $45 \mathrm{~cm}$ high, with lining and side curtains, with accommodation capacity for 21,000 broilers, slaughter ages of 45-48 days with an average weight of $2.85 \mathrm{~kg}$.

Aviary 3: the dimensions of aviary 3 are $12.5 \mathrm{~m}$ wide by $150 \mathrm{~m}$ long and $3.15 \mathrm{~m}$ high, covered with aluminum tiles, having side low walls with $40 \mathrm{~cm}$ high, with lining and side curtains, with accommodation capacity for 30,000 broilers, slaughter ages of 45-48 days with an average weight of $2.8 \mathrm{~kg}$.

Aviary 4: the dimensions of aviary 4 are $15 \mathrm{~m}$ wide by $150 \mathrm{~m}$ long and $2.75 \mathrm{~m}$ high, covered with aluminum tiles, with side low walls $45 \mathrm{~cm}$ high, with lining and side curtains, with accommodation capacity for 35,000 broilers, slaughter ages of 45-48 days with an average weight of $2.8 \mathrm{~kg}$.

The aviaries studied have the following equipment and installed loads:

Aviary 1: the aviary 1 contains 56 incandescent bulbs of $60 \mathrm{~W}$ each, 6 engines of $1.5 \mathrm{hp}$ each to provide energy to the exhaustion system, 4 engines of $1.5 \mathrm{hp}$ each to provide energy to the feeder system, 1 engine of $1.5 \mathrm{hp}$ to provide energy to the drinking fountain system, 1 engine of $4 \mathrm{hp}$ to provide energy to the heating system and 1 engine of $2 \mathrm{hp}$ to provide energy to the nebulization system.

Aviary 2: the aviary 2 contains 56 incandescent bulbs of $60 \mathrm{~W}$ each, 8 engines of $1 \mathrm{hp}$ each to provide energy to the exhaustion system, 4 engines of $1.5 \mathrm{hp}$ each to provide energy to the feeder system; 1 engine of $1.5 \mathrm{hp}$ to provide energy to the drinking fountain system; 1 engine of $4 \mathrm{hp}$ to provide energy to the heating system and 1 engine of $2 \mathrm{hp}$ to provide energy to the nebulization system.

Aviary 3: the aviary 3 contains 66 incandescent bulbs of $60 \mathrm{~W}$ each, 12 engines of $1 \mathrm{hp}$ each to provide energy to exhaustion system, 4 engines of $1.5 \mathrm{hp}$ each to provide energy to the feeder system, 1 engine of $1.5 \mathrm{hp}$ to provide energy to drinking fountain system, 2 engines of $0.5 \mathrm{hp}$ to provide energy to the cooling system, 2 engines of 3 hp each and 1 engine of $0.5 \mathrm{hp}$ to provide energy to the heating system, 1 engine of $3 / 4 \mathrm{hp}$ to provide energy to the opening and closing of side curtains system, 1 engine of $1 / 3 \mathrm{hp}$ for opening and closing of side windows system and 1 engine of $2 \mathrm{hp}$ to provide energy to the nebulization system. On March 10, 201466 incandescent bulbs of $60 \mathrm{~W}$ each were replaced by $98 \mathrm{LED}$-type lamps of $10 \mathrm{~W}$ each.

Aviary 4: the aviary 4 contains 98 LED-type lamps of $10 \mathrm{~W}$ each, 12 engines of $1 \mathrm{hp}$ each to provide energy for the exhaustion system, 5 engines of $1.5 \mathrm{hp}$ each to the provide energy to the feeder system, 1 engine of $1.5 \mathrm{hp}$ to provide energy to the drinking fountain system, 2 engines of $0.5 \mathrm{hp}$ to provide energy to the cooling system, 2 
engines of $3 \mathrm{hp}$ each and 1 engine of $0.5 \mathrm{hp}$ to provide system to the heating system, 1 engine of $3 / 4 \mathrm{hp}$ to provide energy to the opening and closing side curtains system, 1 engine of $1 / 3 \mathrm{hp}$ for opening and closing system of the side windows and 1 engine of $2 \mathrm{hp}$ to provide energy to the nebulization system.

The sum of the loads installed in all aviaries is approximately $89.4 \mathrm{~kW}$. The farm studied shows a pattern of electrical power input of $127 \mathrm{~V}$, single phase registered by the local electric utility as consumer Rural/Rural Rate Night-broiler breeding. In this type of electricity pricing, during the study period, covering the period from 6:01 am to 9:29 pm, the $\mathrm{kWh}$ value is $\mathrm{R} \$ 0.174$ and the time during the period from 9:30 pm to 6 am of the following day, the $\mathrm{kWh}$ value is $\mathrm{R} \$ 0.070$, i.e., the producer receives a discount of approximately $60 \%$ at night.

There are three independent energy inputs, one of which contains a transformer of $15 \mathrm{kVA}$ to provide energy to Aviary 1, the second contains a transformer of $25 \mathrm{kVA}$ to provide energy to Aviary 2 and the third one contains two transformers of $25 \mathrm{kVA}$ each to provide energy to aviary 3 and 4 .

Aviaries study have independent power meters, electronic type, single phase, Landis + Gyr brand, model ZMD318 120V CMt-8055, with active power measurement. Using the electricity meters installed in the aviaries, weekly data of each aviary were collected by the owners, and the active energy values for the existing difference in the previous week and the current week, totaling nine measurements per batch, being the first week corresponding to the aviary empty state and the last week corresponding to the loading state of birds.

The empty aviary state is the period in which the poultry are being prepared to receive the birds. The loading state corresponds to the state in which the birds are about to be loaded onto trucks that carry out the transportation to the slaughterhouses.

This procedure was repeated for the subsequent lots for each aviary under study, so as to obtain the data for six lots corresponding to a year of poultry accommodation totaling two hundred and sixteen measurements.

From the total consumption of active energy, it was calculated the average daily electricity consumption ( $\mathrm{kWh}$ ) for the set of aviaries. This value was used as input for the sizing of the battery banks.

To attend the existing loads in the aviaries, two scenarios have been established using battery banks to store energy in the period from 9:30 pm to 6 am of the following day (period of low electricity pricing) and use the energy from the batteries during the time from 6:01 am to 9:29 pm (period of high electricity pricing).

In the first scenario, batteries of nickel chloride and sodium were used, ST523 model Fiamm Sonic manufacturer with the following characteristics: nominal operating voltage of $620 \mathrm{~V} \mathrm{DC}$, rated current capacity of $38 \mathrm{Ah}, 240$ cells, 4500 cycles to $80 \%$ depth of discharge, dimensions of $624 \mathrm{~mm}$ wide, $1023 \mathrm{~mm}$ deep and $406 \mathrm{~mm}$ high.

In the second scenario, lead-acid batteries were used, DF4001 model, Ac Delco manufacturer with the following characteristics: Rated operating voltage of $12 \mathrm{~V} \mathrm{DC}$, rated current capacity of 200 Ah (10 hours), 1.2 years lifetime at $50 \%$ depth of discharge, dimensions of $280 \mathrm{~mm}$ wide, $530 \mathrm{~mm}$ deep and $246 \mathrm{~mm}$ of height, weight $59.90 \mathrm{~kg}$.

It was evaluated the technical capacity of power supply depending on the depth of discharge of the battery adopted. The depth of discharge generates useful energy potential that will be used to supply the energy of the aviaries set of the property.

Fiamm Sonic (2015) recommends a maximum depth of discharge of $80 \%$ for batteries of nickel chloride and sodium.

Pinho and Galdino (2014) recommend that the maximum depth of discharge of stationary lead-acid batteries should not exceed $50 \%$.

The dimensioning calculations of the battery banks were based on Equations (1) and (2) proposed by Pinho and Galdino (2014) and shown below.

$$
\mathrm{CBB}=\frac{\mathrm{L} \cdot \mathrm{D}}{\mathrm{M}}
$$

where, CBB: battery bank capacity (Ah); L: ampere-hour consumption by charge in one day (Ah/d); D: number of days of autonomy, and M: maximum depth of discharge.

$$
\mathrm{N}=\frac{\mathrm{CBB}}{\mathrm{CB}}
$$

where, N: number of batteries, and CB: selected battery capacity (Ah).

The analysis of the economic aspects involved in each battery technology adopted in the study was made after sizing the battery banks. Posteriorly, the economic evaluation based on the methods of net present value 
proposed by Gitman (2002) was made, according to the Equation (3), which indicated the answer on the feasibility of the proposed use of two types of battery bank for aviary set under in study.

$$
\mathrm{NPV}=\mathrm{ii}-\sum_{0}^{\mathrm{t}} \frac{\mathrm{C}}{(1+\mathrm{K})^{\mathrm{t}}}
$$

where, NPV: net present value; $\mathrm{C}$ : net cash inflow during the period $\mathrm{t} ; \mathrm{K}$ : minimum rate of return; $\mathrm{t}$ time, and ii: initial investment.

In this case, the decision criterion to accept or not the project is as follows: if the NPV is greater than or equal to zero, the project is accepted, otherwise it is rejected. If NPV is greater than zero indicates that the investor will obtain a higher return than its cost of capital.

Cervi, Esperancini, and Bueno (2010) while conducting study on the development model to scale integrated renewable energy systems applied in rural environments concluded that the design of energy systems are essential for making decisions on rural energization projects, which should be considered the technical and economic criteria.

\section{Results}

The data of active energy consumption were collected for each aviary for a year of bird housing. In the period were housed about 600,000 birds, with the consumption of active power in all batches of $176,260 \mathrm{kWh}$, comprising a number ratio of $0.29 \mathrm{kWh} /$ bird housed.

It is observed that for the set of four aviaries of the property over one year of poultry housing, on average, $72 \%$ of the total consumption of active energy occurred during the time when the electricity tariff is $\mathrm{R} \$ 0.174 / \mathrm{kWh}$ and $28 \%$ during the time when the electricity tariff is $\mathrm{R} \$ 0.07 / \mathrm{kWh}$.

The average daily intake was calculated from the total consumption of active energy for the four aviaries, $176,260 \mathrm{kWh}$ by dividing it by the number of days over one year of poultry accommodation which was 349 days, resulting in $505.04 \mathrm{kWh} /$ day.

For the design of the battery banks were considered as total loads to provide energy to the bank the value of $505.04 \mathrm{kWh} /$ day. To this value was applied the percentage of $72 \%$, that corresponds to the percentage in which the electricity tariff costs $\mathrm{R} \$ 0.174 \mathrm{kWh}$, resulting in $363.63 \mathrm{kWh}$, period that the batteries would be used to feed the loads. It was considered that in the period in which the electricity tariff costs $\mathrm{R} \$ 0.07 / \mathrm{kWh}$ the batteries will be charged using the power supply of the electric utility. From this value, calculations were made for the dimensioning of the battery banks for both scenarios study and the results are shown in Table 1.

Table 1. Sizing of batteries bank

\begin{tabular}{lll}
\hline Item & Scenario 1 & Scenario 2 \\
\hline $\mathrm{L}$ & 586.5 & 30302.5 \\
$\mathrm{CBB}$ & 733.13 & 60605 \\
$\mathrm{~N}$ & 20 & 304 \\
\hline
\end{tabular}

For the first scenario, the calculations resulted in a bank composed of 20 batteries of nickel chloride and sodium, with the initial investment of the battery bank would be $\mathrm{R} \$ 2,240,000.00$, considering the amount of $\mathrm{R} \$ 112,000.00$ per battery. This amount was considered as an initial investment of the feasibility study.

With the use of these batteries bank, the owner would have a saving with electricity of $\mathrm{R} \$ 22.081,80$. This amount was obtained considering the load of $363.63 \mathrm{kWh} /$ day by multiplying the amount of R $\$ 0.174 / \mathrm{kWh}$, which is the value of the electricity tariff if the owner had to pay for electricity during the day, and multiplying by number of days in a year poultry housing that is 349 days to this study. The amount of the avoided cost of electric energy was considered as an entry revenues for the feasibility study. The outflows of the cash flow are the expendditure on electricity for charging batteries and the expenditure on electricity to power the charges of the four aviaries at night.

Besides, the cost of electricity for charging the batteries in the lower rate period and power loads of the four aviaries at night was calculated. These figures resulted in $\mathrm{R} \$ 8,883.48$ and $\mathrm{R} \$ 3,454.89$, respectively. The amount of $\mathrm{R} \$ 8,883.48$ corresponds to expenses for charging the $363.63 \mathrm{kWh} /$ day at night over a year of poultry housing, calculated by multiplying $363.63 \mathrm{kWh} /$ day for the amount of $\mathrm{R} \$ 0.07 / \mathrm{kWh}$, which is the value of the electricity tariff at night, by the quantity of days that is 349 . Since the amount of $R \$ 3,454.89$ was obtained from 
the difference between the total daily average active power that is $505.05 \mathrm{kWh}$ and the average of active power consumption during the higher tariff period which is $363.63 \mathrm{kWh}$, resulting in $141.42 \mathrm{kWh}$, by multiplying the amount of R $\$ 0.07 / \mathrm{kWh}$ which is the electricity fare at night, multiplying by the number of 349 days related to one year in poultry housing.

From these data it was calculated the net present value, considering 12 years, which is the approximate lifetime of the battery bank informed by Fiamm Sonic manufacturer (2500 cycles at $80 \%$ depth of discharge), a $\mathrm{K}$ minimum attractiveness fee of $12 \%$ per year and the result obtained was of $\mathrm{R} \$ 2,179,645.59$, as Table 2 . Sprenger (2009) did a viability study using a minimum attractiveness fee of $12 \%$ per year, usual in energy sector. Table 2 presents only the costs and revenues for year 1 .

Table 2. Calculation of Net Present Value for Scenario 1

\begin{tabular}{|c|c|c|}
\hline Feasibility Study & Investment & Year 1 \\
\hline (-) Batteries banks $(\mathrm{R} \$)$ & $2,240,000.00$ & - \\
\hline (-) Equity Investment (R\$) & $2,240,000.00$ & - \\
\hline$(+)$ Cost avoidance with electricity $(\mathrm{R} \$)$ & - & $22,081.80$ \\
\hline$(+)$ Net Revenues $(\mathrm{R} \$)$ & - & $22,081.80$ \\
\hline (-) Expenditure on electricity for charging batteries (R\$) & - & $8,883.48$ \\
\hline (-) Expenditure on electricity to power the charges at night (R\$) & - & $3,454.89$ \\
\hline$(=)$ Income Statement $(\mathrm{R} \$)$ & - & $9,743.42$ \\
\hline$(=)$ Result $/(1+12 \%)^{t}$, where, $t=$ year $(R \$)$ & - & $8,699.49$ \\
\hline Net Present Value $(\mathrm{R} \$)$ & $2,179,645.59$ & \\
\hline
\end{tabular}

In the calculations were not considered adjustments to the electricity tariffs, costs for other components of the energy storage system such as inverters, wiring and operating costs and system maintenance over 12 years.

For the second scenario, the calculations resulted in a bank comprised of 304 lead-acid batteries. It happens that, as indicated by the manufacturer Ac Delco (2015), this type of battery has a lifetime of 1.2 years when used at a maximum depth of discharge of $50 \%$. In this case, the battery bank must be replaced every 1.2 years and the investor will have new investments over the period of 12 years, which is the horizon considered for the feasibility study. For the value of the initial investment were considered 304 batteries, multiplied by a value of $\mathrm{R} \$ 922.00$ per battery, multiplied by 10 , which is the number of new battery banks over the period of 12 years, resulting in an amount of $\mathrm{R} \$ 2,802,880.00$. This amount was considered as an initial investment of the feasibility study.

To calculate the Net Present Value referring to this scenario, the same values as the first scenario for the minimum rate of attractiveness were used, cost avoidance with electricity, costs of electricity to charge the batteries and power the charges of the four aviaries in the night period. The result for the net present value was $\mathrm{R} \$ 2,742,525.59$. Table 3 presents only the costs and revenues for year 1 .

Table 3. Calculation of Net Present Value for Scenario 2

\begin{tabular}{|c|c|c|}
\hline Feasibility Study & Investment & Year 1 \\
\hline (-) Batteries bank (R\$) & $2,802,880.00$ & \\
\hline (-) Equity Investment $(\mathrm{R} \$)$ & $2,802,880.00$ & \\
\hline$(+)$ Cost avoidance with electricity $(\mathrm{R} \$)$ & - & $22,081.80$ \\
\hline$(+)$ Net Revenues $(\mathrm{R} \$)$ & - & $22,081.80$ \\
\hline (-) Expenditure on electricity for charging batteries ( $R \$)$ & - & $8,883.48$ \\
\hline (-) Expenditure on electricity to power the charges at night ( $\mathrm{R} \$$ ) & - & $3,454.89$ \\
\hline$(=)$ Income Statement $(\mathrm{R} \$)$ & - & $9,743.42$ \\
\hline Result $/(1+12 \%)^{t}$, where, $t=$ year $(R \$)$ & - & $8,699.49$ \\
\hline Net Present Value (R\$) & $2,742,525.59$ & \\
\hline
\end{tabular}




\section{Discussion}

The results for the first scenario demonstrates the unfeasibility of the proposed use of the battery bank in the higher tariff period and its charge on lower rate period, because, according to Gitman (2002), for a project to be viable, the net present value should be greater than or equal to zero. In this case, the net present value resulted in a negative number, i.e., the owner does not recover its investment over the established 12 years. Pearre and Swan (2014) did a study to map electrical services and energy storage technologies. They concluded that are several aspects that affect the overall performance of a technology, and thus both its technical and economic viability. These include availability to provide service, cycling window, lifetime characteristics, and technology specific constraints. Finally, costs, primarily capital costs, directly affect economic feasibility.

The results showed that both the use of nickel chloride and sodium battery bank as well as the lead-acid batteries proved economically unviable options for the rural poultry farm set in the study.

The study showed that the costs avoided with electricity through the use of these systems, which were the entries of cash flows for the economic feasibility study, in the order of $\mathrm{R} \$ 22,081.80$ annually, are considerably low compared to the initial investment, which contributed to the unfeasibility of the project. According to studies done by Mulder, Six, Claessens, Broes, Omar, and Mierlo, (2013), if the electricity price increseas with 4\% (including the general inflation rate) then batteries become quickly attractive and do not need subsidies.

For the second scenario, it is noted that the number of batteries is higher compared to the first scenario besides the unit values of lead-acid batteries are lower than the batteries of nickel chloride and sodium, however, the lifetime of the lead-acid batteries is lower than the batteries of nickel chloride and sodium, which requires further investment over the 12 years. The battery lifetime contributed to the infeasibility of the project. In this aspect, Kousksou, Bruel, Jamil, El Rhafiki, and Zeraouli (2014) conclude in a study of differente technologies of energy storage that the lifetime of lead acid batteries in severe climatic conditions and remote outdoor installations is unsatisfactory.

It is concluded that for the two study scenarios, investments in energy storage systems with battery bank, either nickel chloride and sodium or lead-acid, are relatively high for rural properties that are already supplied by power supply of the local utility electricity. In this sense, Nair and Garimella (2010) mentioned that employment of battery energy storage technologies within small-scale renewable energy system will take priority when initial capital costs of storage technologies are driven down due to global investment, policy changes increase volatility of power prices and technological changes affect power consumption patterns.

\section{References}

Ac Delco. (2015). Baterias Estacionárias. Retrieved from http://www.acdelcofreedom.com.br/bateria-estacionari as.aspx\#

Agência Nacional de Energia Elétrica. (2014). Audiência Pública 2008. Retrieved from http://www.aneel.gov.br/ aplicacoes/audiencia/arquivo/2008/027/apresentacao/copel___dfilast.pdf

Associação Brasileira dos Produtores e Exportadores de Frangos. (2014). História da Avicultura no Brasil. Retrieved from http://www.ubabef.com.br/a_avicultura_brasileira/historia_da_avicultura_no_brasil

Calixto, L., \& Oliveira, L. T. D (2012). A avicultura como atividade satisfatória para pequenos produtores com o sistema integrado de produção em um município do norte do Paraná. Retrieved from $\mathrm{http}: / /$ docplayer.com.br/4607343-A-avicultura-como-atividade-satisfatoria-para-pequenos-produtores-como-sistema-integrado-de-producao-em-um-municipio-do-norte-do-parana.html

Centrais Elétricas Brasileiras S.A. (2015). Programa Nacional de Conservação de Energia Elétrica-Procel. Retrieved from http://www.eletrobras.com/elb/data/Pages/LUMIS0389BBA8PTBRIE.htm

Cervi, R. G., Esperancini, M. S. T., \& Bueno, O. de C. (2010). Viabilidade econômica da utilização do biogás produzido em granja suínícola para geração de energia elétrica. Engenharia Agrícola, 30(5), 831-844. https://doi.org/10.1590/S0100-69162010000500006

Fiamm Sonic. (2015). Energy Storage Solutions. Retrieved January 12, 2015, from http://fiamm.com/media/ 215334/20141024_st523_datasheet_eng-web.pdf

Gitman, L. J. (2002). Princípios de Administração Financeira (7th ed.). São Paulo, BR: Harbra.

Kousksou, T., Bruel, P., Jamil, A., El Rhafiki, T., \& Zeraouli, Y. (2014). Energy storage: Applications and challenges. Solar Energy Materials and Solar Cells, 120, 59-80. https://doi.org/10.1016/j.solmat.2013. 08.015 
Mulder, G., Six, D., Claessens, B., Broes, T., Omar, N., \& Mierlo, J. (2013). The dimensioning of PV-battery systems depending on the incentive and selling price conditions. Applied Energy, 111, 1126-1135. https://doi.org/10.1016/j.apenergy.2013.03.059

Nair, N.-K. C., \& Garimella, N. (2010). Battery energy storage systems: Assessment for small-scale renewable energy integration. Energy and Buildings, 42(11), 2124-2130. https://doi.org/10.1016/j.enbuild.2010.07.002

Pearre, N. S., \& Swan, L. G. (2014). Technoeconomic feasibility of grid storage: Mapping electrical services and energy storage technologies. Applied Energy, 2-11. https://doi.org/10.1016/j.apenergy.2014.04.050

Pinho, J. T., \& Galdino, M. A. (2014). Manual de Engenharia para Sistemas Fotovoltaicos. Retrieved from https://www.portal-energia.com/downloads/livro-manual-de-engenharia-sistemas-fotovoltaicos-2014.pdf

Sprenger, H. E. (2009). Viabilidade do uso de biogás de ETE para alimentação de células a combustível de ácido fosfórico (Master's thesis, Instituto de Tecnologia para o Desenvolvimento, Curitiba). Retrieved from http://www.institutoslactec.org.br/menu-capacitacao/dissertacao-humberto-elias-sprenger

Yan, X., Zhang, X., Chen, H., Xu, Y., \& Tan, C. (2014). Techno-economic and social analysis of energy storage for commercial buildings. Energy Conversion and Management, 78, 125-136. https://oi.org/10.1016/ j.enconman.2013.10.014

\section{Copyrights}

Copyright for this article is retained by the author (s), with first publication rights granted to the journal.

This is an open-access article distributed under the terms and conditions of the Creative Commons Attribution license (http://creativecommons.org/licenses/by/4.0/). 